\title{
Internet Banking Service Quality: Building Satisfaction and Customer Trust
}

\author{
Kristian Suhartadi Widi Nugraha ${ }^{1}$ \\ ${ }^{1}$ Faculty of Economics and Business, University of Jember, Jember, Indonesia
}

\section{A R T I C L E I N F O}

Article history:

Received 18 January 2021

Received in revised form

25 January 2021

Accepted 06 February 2021

Available online 25

February 2021

Keywords:

Building Satisfaction;

Costumer Trust

\begin{abstract}
A B S T R A C T
This study aims to analyzes how IBSQ variables influence customer satisfaction and trust in state-owned banks in Jember Regency. The sample in this study amounted to 150 with a purposive sampling approach with data collection through questionnaires. The analysis in this study used a structural equation model (SEM-PLS). Research conducted proves that the IBSQ variables, namely personal needs, site organization, user-friendliness, efficiency, responsiveness, reliability, customer satisfaction, and customer satisfaction, affect trust. The six IBSQ variables have their variations and effects on customer satisfaction. In this study, the most significant coefficient that affects satisfaction is reliability. Reliability as the variable with the largest coefficient can be interpreted as system reliability and security, which are the top priority and guarantees in IBSQ. This study's findings indicate that it is essential for banks to improve service quality sustainably to generate competitive and consistent advantages over time. This study's overall results suggest that IBSQ as part of the banking business plays an essential role in forming customer satisfaction. Satisfaction is critical and requires consistent effort and strategy in achieving it.
\end{abstract}

Copyright (C) Universitas Pendidikan Ganesha. All rights reserved.

\section{Introduction}

One of the main aspects of marketing, namely satisfying and satisfying consumer needs in the exchange process carried out (Tjiptono \& Diana, 2020; Wirtz \& Lovelock, 2018) and the problem of healthy customer relations (Boonlertvanich, 2019). Efforts to satisfy consumers with simple sentences but with a complicated process in their application. Customer satisfaction is closely related to how company value can be in sync with consumer value. One of the essential businesses that continue to grow is banking. Financial transactions have developed rapidly and utilize the internet network in every process (Famiyeh et al., 2018). Until now, the concept of technology in your hands is getting closer to the lives of consumers. Likewise, banking is always on, improving services from previously office-based to now internet-based.

The development of banking services using technology and the internet is multiplying. Product and service innovation is currently an integral factor in the banking industry and is inherent in banking services' quality standards. BRI was quoted as saying in a release antaranews.com extended that to June 2020 recorded an increase in internet banking users as much as twice or as many as 24 million customers (Junida, 2020). This makes the banking business, especially in the internet banking aspect, a vital need for consumers and must be managed optimally to avoid dissatisfied consumers and block exit barriers (Kotler \& Keller, 2016; Pollack, 2017).

Internet banking is one of the services provided by service providers to customers. Increasingly dynamic customer activity requires concise, fast, and secure services and is not limited by time and space. Internet banking is an important bank service to ensure fulfilment of customer needs, increase customer engagement and reduce costs for recruiting new customers, which leads to long-term profitability (Raza et al., 2020). To retain customers, management must strive to keep customers satisfied with their services and offerings, which can be achieved by providing quality electronic services. Measurement of quality 
service in various kinds of literature can be interpreted as service quality (Parasuraman et al., 1988). It is commonly called e-service quality (Herington \& Weaven, 2009; Tjiptono \& Chandra, 2019).

Service quality is a means of ensuring customer satisfaction, trust, and even loyalty (Boonlertvanich, 2019; Namahoot \& Laohavichien, 2018; Patel \& Patel, 2018). The service quality model is currently developing rapidly and is adapted to the conditions and situations at hand. Understanding the concept of service quality and its impact will help managers manage organizational performance (Alnaser et al., 2018; Boonlertvanich, 2019; Rahi et al., 2020). Also, service quality not only focuses on new customers but also on how to build relationships and strengthen relationships with customers who have been customer-equipped for a long time.

The concept of e-service quality has several gaps that need to be studied and resolved (Tjiptono \& Chandra, 2019), namely information gap, design gap, communication gap, and fulfilment gap. Information gap describes the gap between consumer needs and company management regarding meeting consumer needs. The design gap leads to more if the company or service provider cannot provide and utilize all knowledge optimally regarding the features that customers expect into the intended website function. The communication gap can be seen as the staff's communication skills on managing information, understanding products, and the ability to provide solutions to consumer problems. The last hole is the fulfilment gap, which reflects the overall gap between consumer needs and consumers' experiences. Increasing e-service quality is still seen as a strategic step to increase customer satisfaction and behavioral intention (Pakurár et al., 2019; Shankar \& Jebarajakirthy, 2019; Yuan et al., 2019).

The finding regarding gaps in the study of e-service quality raises many approaches in developing variables adapted to various conditions at hand. Ho \& Lin (2010), in their research on internet banking service quality (IBSQ), uses four variables, namely web design, customer service, assurance, and order management. Ariff et al (2013) developed IBSQ into five variables: website aesthetic \& guide, efficiencysystem availability, contact-responsiveness, privacy, and assurance-fulfilment. Likewise, several experts developed IBSQ into several variables, including personal needs, site organization, user-friendliness, website efficiency, responsiveness, and reliability (Amin, 2016; Herington \& Weaven, 2009; Raza et al., 2020; Tjiptono \& Chandra, 2019).

This study aims to determine and analyze the influence of the variables in IBSQ by replicating the findings of Raza et al (2020) on customer satisfaction and customer trust. Evaluation of service quality can vary according to customer perceptions (Shankar \& Jebarajakirthy, 2019), so it needs a sharp analysis of the IBSQ variable, which is used as a predictor of customer satisfaction trust. Conceptually, research is being conducted to bridge the four gaps in electronic service quality on internet banking. IBSQ as an implementation of superior service quality must be used as a competitive organizational strategy and a vehicle for maintaining corporate sustainability (Herington \& Weaven, 2009; Tjiptono \& Chandra, 2019). If this is done consistently and measurably, it will have the potential to build customer satisfaction, which in the long run will have a behavioral impact such as business growth opportunities, word of mouth, customer trust, and beneficial relationship relationships (Boonlertvanich, 2019; Ga \& Sa, 2005; Namahoot \& Laohavichien, 2018; Raza et al., 2020).

\section{Methods}

Research conducted with a quantitative approach to explain IBSQ variables' role on customer satisfaction and customer trust (Amin, 2016; Ariff et al., 2013; Herington \& Weaven, 2009; Ho \& Lin, 2010; Raza et al., 2020). Data collection using a questionnaire with variable characteristics using a Likert scale. This study's analysis uses structural equation modeling (SEM-PLS) to correct measurement errors by incorporating interaction effects in the model (Ghozali, 2014) with software SMARTPLS 03. The purpose of the SEM-PLS estimation is to make the best score components from endogenous variables. Also, SEMPLS is used to predict the relationship between variables and indicators through the inner model, namely the relationship between latent variables and the outer model, namely the relationship between indicators and their latent variables (Ghozali, 2014).

The population in this study were customers of state-owned banks in Jember Regency. This study uses the purposive sampling technique as a sampling technique. The number of samples taken is 135 samples obtained from the total number of indicators multiplied by numbers 5 to 10 . The total number of indicators is 27 indicators multiplied by 5 , and the results are 135 . However, in its implementation, from the questionnaires distributed online, 150 respondents met the conditions. It was decided that 150 respondents were taken to argue that they met the minimum requirements for sampling. 


\section{Results and Discussions}

\section{Results}

The characteristics of the respondents in the study are shown in Table 1.

Table 1. Characteristics of Respondents

\begin{tabular}{|c|c|c|}
\hline \multicolumn{3}{|c|}{ Gender } \\
\hline Characteristics & Total & Percentage \\
\hline Man & 107 & $71 \%$ \\
\hline Women & 43 & $29 \%$ \\
\hline Total & 150 & $100 \%$ \\
\hline \multicolumn{3}{|c|}{ Respondent Age } \\
\hline Characteristics & Total & Percentage \\
\hline 20 years -30 years & 6 & $4 \%$ \\
\hline 31 years -40 years & 56 & $37 \%$ \\
\hline 41 years - 50 years & 54 & $36 \%$ \\
\hline 51 years - 60 years & 20 & $13 \%$ \\
\hline 61 years -70 years & 14 & $9 \%$ \\
\hline Total & 150 & $100 \%$ \\
\hline \multicolumn{3}{|c|}{ Occupation } \\
\hline Characteristics & Total & Percentage \\
\hline Business Owners & 98 & $65 \%$ \\
\hline Government Employees & 26 & $17 \%$ \\
\hline Private Employees & 24 & $16 \%$ \\
\hline College student & 2 & $1 \%$ \\
\hline Total & 150 & $100 \%$ \\
\hline
\end{tabular}

Based on Table 1 regarding respondents' characteristics, it was found that as many as 150 respondents in the study were conducted from the gender side of $71 \%$ or 107 respondents were male, and $29 \%$ or 43 respondents were female. The characteristics of the respondents' age, dominant at the age of 31 years to 50 years, were $37 \%$ and $36 \%$, while the rest were in the young age range as much as $4 \%$ and elderly as much as $9 \%$. The respondents' job characteristics found that $65 \%$ or 98 respondents were business owners or businessmen, $17 \%$ or 26 respondents were government employees, $16 \%$, or 24 respondents were private employees, and $1 \%$ or two respondents were students.

Table 2. Validity Test Results

\begin{tabular}{|c|c|c|c|}
\hline Variabel & Loading Factor & AVE & Information \\
\hline \multirow{3}{*}{ Personal needs } & 0,943 & \multirow{3}{*}{0,845} & \multirow{3}{*}{ Valid } \\
\hline & 0,906 & & \\
\hline & 0,909 & & \\
\hline \multirow[t]{3}{*}{ Site Organization } & 0,963 & \multirow{3}{*}{0,923} & \multirow{3}{*}{ Valid } \\
\hline & 0,958 & & \\
\hline & 0,803 & & \\
\hline \multirow{3}{*}{ User Friendliness } & 0,861 & \multirow{4}{*}{0,719} & \multirow{3}{*}{ Valid } \\
\hline & 0,823 & & \\
\hline & 0,902 & & \\
\hline \multirow{3}{*}{ Efficiency } & 0,910 & & \multirow{3}{*}{ Valid } \\
\hline & 0,889 & \multirow[t]{2}{*}{0,826} & \\
\hline & 0,928 & & \\
\hline \multirow{4}{*}{ Responsiveness } & 0,891 & \multirow{4}{*}{0,766} & \multirow{3}{*}{ Valid } \\
\hline & 0,881 & & \\
\hline & 0,822 & & \\
\hline & 0,897 & & \multirow{4}{*}{ Valid } \\
\hline \multirow[t]{3}{*}{ Reliability } & 0,862 & \multirow{3}{*}{0,766} & \\
\hline & 0,876 & & \\
\hline & 0,872 & & \\
\hline
\end{tabular}




\begin{tabular}{cccc}
\hline Variabel & Loading Factor & AVE & Information \\
\hline & 0,867 & & \\
0,877 & & \\
Customer Satisfaction & 0,881 & & Valid \\
& 0,848 & 0,741 & \\
& 0,852 & & Valid \\
Trust & 0,926 & & \\
& 0,707 & 0,734 & \\
\hline
\end{tabular}

Based on Table 2, the first step of model evaluation is to measure the construct's validity by looking at the loading factor and AVE values (Ghozali, 2014). The results of the calculations shown in table 2 show that the loading factor value is $>0.7$. The AVE value for each construct is $\geq 0.5$, which means that all indicators for variables of personal needs, site organization, user-friendliness, efficiency, responsiveness, reliability, customer satisfaction, and customer trust are categorized as valid. All eight constructs are classified as valid (Hamid \& Anwar, 2019).

Table 3. Reliability Test Results

\begin{tabular}{lccc}
\hline \multicolumn{1}{c}{ Variabel } & Cronbach Alpha & Composite Reliability & Information \\
\hline Personal Needs & 0,909 & 0,943 & Reliable \\
Site Organization & 0,916 & 0,960 & Reliable \\
User Friendliness & 0,870 & 0,911 & Reliable \\
Efficiency & 0,895 & 0,934 & Reliable \\
Responsiveness & 0,831 & 0,899 & Reliable \\
Reliability & 0,939 & 0,952 & Reliable \\
Customer Satisfaction & 0,826 & 0,895 & Reliable \\
Trust & 0,820 & 0,891 & Reliable \\
\hline
\end{tabular}

Based on Table 3, after conducting the validity test, the reliability test can be seen from composite reliability results and seeing the Cronbach alpha coefficient (Hamid \& Anwar, 2019). According to the information presented in table 3 , it appears that the value of composite reliability is $>0.7$, and the Cronbach alpha coefficient is also $\geq 0.7$, which means that the variables used are categorized as reliable and consistent.

Table 4. $\mathrm{R}^{2}$ Result

\begin{tabular}{cc}
\hline Information & $\mathbf{R}^{2}$ Result \\
\hline Customer Satisfaction & 0,748 \\
Trust & 0,606 \\
\hline
\end{tabular}

Inner model testing is done by looking at the $\mathrm{R}$ square value and the significance value. Based on the research output shown in Table 4 , the $\mathrm{R}$ square result for customer satisfaction is 0.748 , and confidence is 0.606 . The meaning of these results is the variable of customer satisfaction can be explained by the predictors by $74,8 \%$, and variable trust can be explained by the customer satisfaction of $60.6 \%$.

Table 5. $Q^{2}$ Result

\begin{tabular}{cc}
\hline Keterangan & $\mathbf{Q}^{\mathbf{2}}$ Result \\
\hline Customer Satisfaction & 0,542 \\
Trust & 0,429 \\
\hline
\end{tabular}

The inner model test is carried out by looking at the predictive relevance (Q2) value in addition to the R square. The magnitude of Q2 has a value with a range of $0<Q 2<1$, where the closer to 1 means that the model is getting better (Ghozali, 2014). The $Q 2$ test is carried out through a blindfolding process. The predictive relevance value calculation for the customer satisfaction variable of 0.542 or $54.2 \%$ and the trustworthiness of 0.429 or $42.9 \%$. This indicates that the model has predictive relevance to observe customer satisfaction and trust variables. Based on the predictive relevance value, the model can be said to be good or has an excellent predictive value to be used for hypothesis testing. 
Table 6. Path Coefficient and Hypothesis Test Results

\begin{tabular}{lccc}
\hline \multicolumn{1}{c}{ Path } & Path Coefficient & p-value & Information \\
\hline Personal Needs-Cust.Satisfaction & 0,230 & 0,017 & Significant \\
Site Organization- Cust.Satisfaction & 0,247 & 0,020 & Significant \\
User Friendliness-Cust.Satisfaction & 0,385 & 0,013 & Significant \\
Efficiency- Cust.Satisfaction & 0,457 & 0,004 & Significant \\
Responsiveness- Cust.Satisfaction & 0,354 & 0,000 & Significant \\
Reliability- Cust.Satisfaction & 0,668 & 0,000 & Significant \\
Cust.Satisfaction -Trust & 0,781 & 0,000 & Significant \\
\hline
\end{tabular}

Table 6 shows that all the hypotheses in this study are significant. The personal needs variable affects customer satisfaction with a path coefficient of 0,230 and a p-value of 0,017 , so that $\mathrm{H} 1$ in this study is accepted. Likewise, $\mathrm{H} 2$ regarding site organization's effect on satisfaction is received with a path coefficient of 0,247 with a p-value of 0,020. The effect of User Friendliness on customer satisfaction has a path coefficient of 0.385 with a p-value of 0,013 , which means that $\mathrm{H} 3$ in this study is accepted. $\mathrm{H} 4$ regarding customer satisfaction's efficiency is stated to be accepted with a path coefficient value of 0,457 and a p-value of 0,004 . The effect of responsiveness on customer satisfaction has a path coefficient of 0,354 with a p-value of 0,000 , which means that $\mathrm{H} 5$ is accepted. Likewise, the effect of reliability on customer satisfaction has a path coefficient of 0,668 with a p-value of 0,000 , which means $\mathrm{H} 6$ is accepted. H7 regarding customer satisfaction with trust is stated to be accepted with a path coefficient value of 0,781 with a p-value of 0,000 .

\section{Discussions \\ Effect of Personal Needs on Customer Satisfaction}

The results showed that personal needs had a significant effect on customer satisfaction. The central concept applied is that management can manage customer requests, understand customer needs, and express its services. Customer's personal needs can be appropriately addressed with various existing features and optimal services. Service can mean how to serve customers according to their respective characteristics. In this case, management is required to create a product and system that is friendly to customer segments and target customers. According to the respondent's profile, it can be seen that the majority are businessmen or entrepreneurs who need reliable internet banking access and understand the needs and wants of customers. Generally, customers need something simple but reliable and according to their needs (Chu et al., 2012). This study's results align with research findings (Amin, 2016; Raza et al., 2020), which states that personal needs affect customer satisfaction.

\section{Effect of Site Organization on Customer Satisfaction}

Based on the research results, the site organization variable has a significant effect on customer satisfaction. Site organization is the home page that the customer first sees. First-time impressions and attractive visual aspects are one of the company's strategies. Site organization is a description of the first attribute seen by customers and even consumers who are not yet customers, so it is the first point of interest that must be worked on by management. Rahi et al (2020) stated that site organization or web design is one factor that contributes to customer satisfaction; even web design becomes a display of identity that will show an image of quality and consistency in maintaining services. This study's results are also in line with respondents' profile, where the majority are aged 31 years to 50 years, who are generally of productive and dynamic age so that a credible appearance will be the central drawer. An attractive and well-organized site organization will make customers comfortable and contribute to building customer satisfaction (Amin, 2016; Ariff et al., 2013; Ho \& Lin, 2010).

\section{Effect of User Friendliness on Customer Satisfaction}

Based on the research results, it was found that user-friendliness has a significant effect on customer satisfaction. The ease of using online banking applications makes consumers feel comfortable and learn quickly to understand the transaction system presented. Even from several free interviews conducted, the ease of using internet banking is the main factor which is the reason besides appearance and security. These findings are closely related to the age range of respondents, most of whom are in the field of 31 years to 50 years, which is the peak productive age in work or career. Also, seeing the characteristics of users, $65 \%$ are entrepreneurs, which means that online banking activities are carried out for business transactions in addition to personal transactions. These findings confirm the findings of 
Amin (2016), Raza et al (2020), and Hammoud et al (2018), which emphasize that customers who feel easy and comfortable accessing internet banking affect customer satisfaction.

\section{Effect of Efficiency on Customer Satisfaction}

The results showed that efficiency had a positive and significant effect on customer satisfaction. Efficiency is one of the main drivers in measuring IBSQ because of the transaction weight's maximum and complete efficiency. Technical and functional aspects are also one of the essential jobs in managing internet banking. In simple terms, this concept can be interpreted as the more efficient a transaction process in IBSQ; the more satisfied customers will be. A compact and straightforward transaction system is one of the company's advantages in serving customers (Herington \& Weaven, 2009). Hammoud et al (2018) also stated that efficiency is cost-effective and time-consuming, and flexible to access. Looking at the distribution of respondents both in terms of gender, age and occupation, the efficiency factor is an important variable in measuring IBSQ because the efficiency and practicality of the application make customer time not wasted and have an impact on customer satisfaction (Amin, 2016; Ariff et al., 2013).

\section{Effect of Responsiveness on Customer Satisfaction}

The results showed that responsiveness had a positive and significant effect on customer satisfaction. Responsiveness is a major variable used in evaluating the quality of banking services (Raza et al., 2020). Responsiveness generally refers to the accuracy and speed of management's response to various obstacles and problems found in the field. Although digital-based, customer care response to customers remains a major concern in the context of service. Responsiveness in IBSQ can be interpreted as the proper regulation and operation of system functions; the information system on internet banking can guide customers if problems occur and can provide solutions to problems (Raza et al., 2020). The most important thing is the fast and precise response of the customer care in handling customer complaints. Various references agree that consumers in any business want to be noticed and served quickly and precisely and prioritize every service (Boonlertvanich, 2019; Evans et al., 2010; Kotler et al., 2017; Tham et al., 2019). Responsiveness in IBSQ is getting better managed and can affect customer satisfaction (Nimako et al., 2013; Raza et al., 2020).

\section{Effect of Reliability on Customer Satisfaction}

The results showed that reliability has a positive and significant effect on customer satisfaction. In this study, reliability has the largest path coefficient that affects customer satisfaction, namely 0.668. Reliability is closely related to reliability and consistency in carrying out banking duties. Also, aspects of data confidentiality and protection of information and transactions are considered safe. Some researchers even consider reliability a significant determinant of banking performance (Ho \& Lin, 2010; LiébanaCabanillas et al., 2013; Raza et al., 2020). The reliability of a banking system is one of the current competitive strengths and strategies (Famiyeh et al., 2018). Banking is a business of trust, so every aspect must rely on transparency and security guarantees against potential security that may occur. In general, customers generally access internet banking for the first time; besides looking at the display, it will ensure network security, system security, data confidentiality, and transaction security. Reliability on the IBSQ is considered an important variable and contributes to building customer satisfaction (Ariff et al., 2013; Raza et al., 2020).

\section{Effect of Satisfaction on Customer Trust}

The results showed that customer satisfaction had a significant effect on customer trust. Customer satisfaction is an evaluation of the promises made by the service provider. Satisfied consumers or customers have a long-term impact in shaping consumer trust (Boonlertvanich, 2019; Pakurár et al., 2019; Suryaningsih et al., 2020). Referring to the profile of respondents, all agree that customer satisfaction is an absolute customer must feel. Also, consistency in providing services and management's ability to provide more services will impact companies' sense of belonging with consumers (Berezina et al., 2012; Ghane et al., 2011; Manrai \& Manrai, 2007; Pollack, 2017). Customer satisfaction and trust are absolute things that must be achieved as an indicator of service performance and company performance. There are many ways to achieve satisfaction and trust, but the point is how the company can serve consumers according to expectations and how the company consistently provides services and updates and upgrades regularly according to changing needs and competes in the disruptive era (Kotler \& Keller, 2016; Tjiptono \& Chandra, 2019). 


\section{Conclusion}

Research conducted proves that the IBSQ variables, namely personal needs, site organization, user-friendliness, efficiency, responsiveness, reliability, customer satisfaction, and customer satisfaction, affect trust. The six IBSQ variables have their variations and effects on customer satisfaction. In this study, the most significant coefficient that affects satisfaction is reliability. Reliability as the variable with the largest coefficient can be interpreted as system reliability and security, which are the top priority and guarantees in IBSQ. This study's findings indicate that it is essential for banks to improve service quality sustainably to generate competitive and consistent advantages over time. This study's overall results suggest that IBSQ as part of the banking business plays an essential role in forming customer satisfaction. Satisfaction is critical and requires consistent effort and strategy in achieving it.

\section{References}

Alnaser, F. M. I., Ghani, M. A., \& Rahi, S. (2018). Service quality in Islamic banks: The role of PAKSERV model, customer satisfaction and customer loyalty. Accounting, 4(2), 63-72. https://doi.org/10.5267/j.ac.2017.8.001.

Amin, M. (2016). Internet banking service quality and its implication on e-customer satisfaction and ecustomer loyalty. International Journal of Bank Marketing, 34(3), 280-306. https://doi.org/10.1108/IJBM-10-2014-0139.

Ariff, M. S. M., Yun, L. O., Zakuan, N., \& Ismail, K. (2013). The Impacts of Service Quality and Customer Satisfaction on Customer Loyalty in Internet Banking. Procedia - Social and Behavioral Sciences, 81, 469-473. https://doi.org/10.1016/j.sbspro.2013.06.462.

Berezina, K., Cobanoglu, C., Miller, B. L., \& Kwansa, F. A. (2012). The impact of information security breach on hotel guest perception of service quality, satisfaction, revisit intentions and word-of-mouth. International Journal of Contemporary Hospitality Management, 24(7), 991-1010. https://doi.org/10.1108/09596111211258883.

Boonlertvanich, K. (2019). Service quality, satisfaction, trust, and loyalty: the moderating role of mainbank and wealth status. International Journal of Bank Marketing, 37(1), 278-302. https://doi.org/10.1108/IJBM-02-2018-0021.

Chu, P. Y., Lee, G. Y., \& Chao, Y. (2012). Service quality, customer satisfaction, customer trust, and loyalty in an e-banking context. Social Behavior and Personality, 40(8), 1271-1284. https://doi.org/10.2224/sbp.2012.40.8.1271.

Evans, M., Jamal, A., \& Foxall, G. (2010). Consumer Behaviour. In Behaviour (Vol. 29, Issue 1). https://doi.org/papers2://publication/uuid/BE8792F6-01FC-4338-8046-B7414F15446B.

Famiyeh, S., Asante-Darko, D., \& Kwarteng, A. (2018). Service quality, customer satisfaction, and loyalty in the banking sector. International Journal of Quality \& Reliability Management, 35(8), 1546-1567. https://doi.org/10.1108/ijqrm-01-2017-0008.

Ga, J. C., \& Sa, M. (2005). Effects of service quality dimensions on behavioural purchase intentions. 1991. https://doi.org/10.1108/09604520710735164.

Ghane, S., Fathian, M., \& Gholamian, M. R. (2011). Full relationship among e-satisfaction, e-trust, e-service quality, and e-loyalty: The case of Iran e-banking. Journal of Theoretical and Applied Information Technology, 33(1), 1-6.

Ghozali, I. (2014). Structural Equation Model Metode Alternatif dengan Partial Least Squares (PLS) (4th ed.). Badan Penerbit Universitas Diponegoro.

Hamid, R. S., \& Anwar, S. M. (2019). STRUCTURAL EQUATION MODELING ( SEM ) BERBASIS VARIAN Konsep Dasar dan Aplikasi Program Smart PLS 3.2.8 dalam Riset Bisnis (I, Issue Juni). Pt. Inkubator Penulis Indonesia.

Hammoud, J., Bizri, R. M., \& El Baba, I. (2018). The Impact of E-Banking Service Quality on Customer Satisfaction: Evidence From the Lebanese Banking Sector. SAGE Open, 8(3), 1-12. https://doi.org/10.1177/2158244018790633.

Herington, C., \& Weaven, S. (2009). E-retailing by banks: E-service quality and its importance to customer satisfaction. European Journal of Marketing, 43(9), 1220-1231. 
https://doi.org/10.1108/03090560910976456.

Ho, C. T. B., \& Lin, W. C. (2010). Measuring the service quality of internet banking: Scale development and $\begin{array}{llll}\text { validation. } & \text { European } & \text { Business } & \text { Review, }\end{array}$ https://doi.org/10.1108/09555341011008981.

Junida, A. I. (2020). BRI catat kenaikan pengguna internet banking hingga 24 juta nasabah. Antaranews.Com.

Kotler, P., Kartajaya, H., \& Setiawan, I. (2017). Marketing 4.0 Moving from Tradisional to Digital. Wiley.

Kotler, P., \& Keller, K. L. (2016). Marketing Management. In Pearson Education Limited (15e ed., Vol. 15E, Issue 4). Pearson. https://doi.org/10.1080/08911760903022556.

Liébana-Cabanillas, F., Muñoz-Leiva, F., \& Rejón-Guardia, F. (2013). The determinants of satisfaction with e-banking. Industrial Management and Data Systems, 113(5), 750-767. https://doi.org/10.1108/02635571311324188.

Manrai, L. A., \& Manrai, A. K. (2007). A field study of customers' switching behavior for bank services. Journal of Retailing and Consumer Services, 14(3), 208-215. https://doi.org/10.1016/j.jretconser.2006.09.005.

Namahoot, K. S., \& Laohavichien, T. (2018). Assessing the intentions to use internet banking: The role of perceived risk and trust as mediating factors. International Journal of Bank Marketing, 36(2), 256276. https://doi.org/10.1108/IJBM-11-2016-0159.

Pakurár, M., Haddad, H., Nagy, J., Popp, J., \& Oláh, J. (2019). The service quality dimensions that affect customer satisfaction in the Jordanian banking sector. Sustainability, 11(4), 1-24. https://doi.org/10.3390/su11041113.

Parasuraman, A., Zeithaml, V. A., \& Berry, L. L. (1988). Servqual : A Multiple-Item Scale for Measuring Consumer Perceptions of Service Quality. Journal of Retailing, 64(1).

Patel, K. J., \& Patel, H. J. (2018). Adoption of internet banking services in Gujarat. International Journal of Bank Marketing, 36(1), 147-169. https://doi.org/10.1108/ijbm-08-2016-0104.

Pollack, B. L. (2017). Effects of exit barriers on word of mouth activities. Journal of Services Marketing, 31(6), 512-526. https://doi.org/10.1108/JSM-01-2016-0024.

Rahi, S., Ghani, M. A., \& Ngah, A. H. (2020). Factors propelling the adoption of internet banking: The role of e-customer service, website design, brand image and customer satisfaction. International Journal of Business Information Systems, 33(4), 549-569. https://doi.org/10.1504/IJBIS.2020.105870.

Raza, S. A., Umer, A., Qureshi, M. A., \& Dahri, A. S. (2020). Internet banking service quality, e-customer satisfaction and loyalty: the modified e-SERVQUAL model. TQM Journal, 32(6), 1443-1466. https://doi.org/10.1108/TQM-02-2020-0019.

Shankar, A., \& Jebarajakirthy, C. (2019). The influence of e-banking service quality on customer loyalty: A moderated mediation approach. International Journal of Bank Marketing, 37(5), 1119-1142. https://doi.org/10.1108/IJBM-03-2018-0063.

Suryaningsih, I. B., Nugraha, K. W. S., \& Sukmalangga, A. Y. (2020). Reflection of Customer Experience and Destination Image of Tourist Trust through Satisfaction Mediation. Hasanuddin Economics and Business Review, 4(1), 1-6. https://doi.org/10.26487/hebr.v4i1.2329.

Tham, K. W., Dastane, O., Johari, Z., \& Ismail, N. B. (2019). Perceived risk factors affecting consumers' online shopping behaviour. Journal of Asian Finance, Economics and Business, 6(4), 246-260. https://doi.org/10.13106/jafeb.2019.vol6.no4.246.

Tjiptono, F., \& Chandra, G. (2019). Service, Quality \& Customer Satisfaction (5th ed.). ANDI.

Tjiptono, F., \& Diana, A. (2020). Pemasaran. ANDI.

Wirtz, J., \& Lovelock, C. (2018). Essentials of Service Marketing (3rd ed.). Pearson.

Yuan, Y., Lai, F., \& Chu, Z. (2019). Continuous usage intention of Internet banking: a commitment-trust model. Information Systems and E-Business Management, 17(1). https://doi.org/10.1007/s10257018-0372-4. 